\title{
Model of Islamic Education Curriculum Development to Improve Students' Creative Thinking
}

\author{
Aan Hasanah, Qiqi Yuliati Zaqiah and Yeti Heryati \\ UIN Sunan Gunung Djati Bandung \\ Bandung, Indonesia \\ aanhasanah@uinsgd.ac.id
}

\begin{abstract}
This study aimed to develop a curriculum model of Islamic education to promote students' creative thinking. The subject of the study are elementary school students in Bandung, Indonesia. To collect data, the study employed test, observation, interview, and model trial to measure four aspects of students' creative thinking including fluency, flexibility, originality, and elaboration. The results of the study showed that an integrated model of Islamic education curriculum in elementary education was able to develop the four aspects of creative thinking skills. In the meantime, a monoitic model of Islamic education curriculum merely developed fluency and originality; the other two aspects, flexibility and elaboration was not optimally developed by this model. This is due to the fact that the model involved much teachers' domination.
\end{abstract}

Keywords- integrated curriculum; creative thinking; elementary school students

\section{INTRODUCTION}

Curriculum of Islamic education (Pendidikan Agama Islam $(P A I))$ plays a quite central place in education. This is due to the fact that the curriculum aims to shape up good Muslim characters based on Islamic teachings [1]. In addition, curriculum of Islamic education is also expected to develop students' skills in accordance with the development of knowledge, science, and technology. This demands teachers to create students with balanced skills between knowledge and characters. However, the curriculum has been still facing several issues so that curriculum developers make efforts to create one meeting students's needs.

In the latest Indonesia's curriculum, for instance, even though the name of the subject is Islamic education, the concents are separate as aqidah akhlaq, quran hadith, Islam cultural history, and figh. The ideal version of Islamic education curriculum is to promote comprehensive understanding about Islam which involves critical and creative thinking skills.

Reality shows that in Indonesia, students' creative thinking skills are still low. A survey in Bandung, Indonesia, proves that there are activities which are considered difficult to follow by the students. Those difficulties generally invovles problemsolving consisting of mathematical, analytical, and creative skills to find relationship among given facts. In short, those difficult activities are one demanding creative thinking skills.
A study revealed that in elementary schools, the evaluation focused on multiple choice questions merely. In fact, such questions as open-ended and essay should be employed to promote their critical and creative thinking skills. It is suggested teachers in elementary schools use performance test in their evaluation [2].

Not only were elementary school students proven to have low creative thinking skills, their teachers also share the same place. A study showed that science-based teacher candidates only had $36.26 \%$ skills and social science-based elementary school teachers reached $26.62 \%$ of creative thinking skills. In total, teacher candidates only had $34.06 \%$ of creative thinking skills [3]. The creative thinking skills of Diploma 2 Elementary Education student were less than $50 \%$ of the minimum score [4].

Thus, developing a model promoting creative thinking skills is something of importance in all subjects in school, including Islamic Education in Islamic elementary schools. Creative thinking skills are one of the core of education since they are closely related to the improvement of educational output which is good characters of students [5]

This study is trying to develop an learning model integrating several existing social sciences such as social science, civics, language, and arts, in one theme namely "ASIA (An Incredible of Indonesia) in which all the topics are discussed comprehensively. This model has more advantages in comparison with other models since the understanding is holistic, the themes are contextual, and the implementation is efficient. In this thematic integrated model, students' critical and creative thinking skills are measured through four components, as developed by Alvino [6]. The components are elaborated in Table I. 
TABLE I. INDICATORS OF CREATIVE THINKING

\begin{tabular}{|c|c|}
\hline Aspects & Description \\
\hline fluency & $\begin{array}{l}\text { - Coming up with a lot of ideas, answers, } \\
\text { solution, and questions clearly; } \\
\text { - Coming up with a series of problem- } \\
\text { solving options; } \\
\text { - Coming up with more than one answer }\end{array}$ \\
\hline flexibility & $\begin{array}{l}\text { - Being able to raise up various ideas, } \\
\text { answers, and questions, and to see a } \\
\text { certain problem from different points of } \\
\text { view; } \\
\text { - Searching for a series of alternatives; } \\
\text { - Being able to shift approahces and } \\
\text { paradigms. }\end{array}$ \\
\hline originality & $\begin{array}{l}\text { - Being able to come up with new and } \\
\text { unique expressoins; } \\
\text { - Being able to come up with } \\
\text { antimainstream way to express themselves; } \\
\text { - Being able to create antimainstream } \\
\text { combination from certain parts. }\end{array}$ \\
\hline elaboration & $\begin{array}{l}\text { - Being able to develop an idea or a produc; } \\
\text { - Being able to specify details of an object, } \\
\text { an idea, or a situation to be more } \\
\text { interesting. }\end{array}$ \\
\hline
\end{tabular}

In this study, the learning model syntax is as follows. Basic Competence: having the character of tabligh (messenger) as implementation of Prophet Muhammad SAW's story understanding.

Indicators:

- Being able to map out Muhammad's characters in the phases of Mecca and Medina struggle.

- Being able to differentiate Muhammad's struggle in Mecca and that in Medina.

- Being able to mention nine lessons learned from Muhammad.

- Being able to tell Muhammad's struggle in Mecca and Medina in order

Teaching steps in the thematic-integrated Islamic education curriculum is explained in Table II.

TABLE II. TEACHING STEPS OF THEMATIC INTEGRATED ISLAMIC EDUCATION CURRICULUM

\begin{tabular}{|c|c|}
\hline Activity & Description \\
\hline Pre-teaching & $\begin{array}{l}\text { - Teachers greet the students and ask the to pray. } \\
\text { - Teachers check the attendance. } \\
\text { - Teachers inform the students that the theme is "Rasul Allah, my idol" } \\
\text { - Teachers inform the students the following steps: observing, asking questions, exploring, communicating, and concluding. }\end{array}$ \\
\hline $\begin{array}{l}\text { Core } \\
\text { teaching }\end{array}$ & $\begin{array}{l}\text { Implementation } \\
\text { - Stimulation } \\
\text { - Ptudents observe a short movie of Muhammad's story from Mecca to Medina } \\
\text { Students and teachers discuss the short movie } \\
\text { - Data analysis } \\
\text { - Students creat mind-mapping about Muhammad's struggle in Mecca and Medina } \\
\text { Exploration } \\
\text { Teachers go around the class to check whether the students find difficulties } \\
\text { - Snalysis } \\
\text { Students play games and differentiate the struggle phases in Mecca and Medina } \\
\text { Making a big book of Muhammad's struggle in Mecca and Medina (exploration) } \\
\text { Posting the big book (communication) }\end{array}$ \\
\hline $\begin{array}{l}\text { Post- } \\
\text { teaching }\end{array}$ & $\begin{array}{l}\text { - Drawing conclusions } \\
\text { Teachers along with the students draw conclusions/ make resume of what they learn } \\
\text { Teachers open a question and answer session about the current topic. } \\
\text { - Teachers allow the students to give their opinions regarding what they learn } \\
\text { - Teachers conduct evaluation } \\
\text { - Teachers ask all the students to close the session by praying together }\end{array}$ \\
\hline
\end{tabular}

\section{RESEARCH METHODOLOGY}

The data of this study derived from students and teachers of elementary schools in West Java, Indonesia. To collect the data, this study used performance and project tests which evaluate students' creative thinking. In the meantime, the implementation of learning model was acquired through the teaching and learning sessions as well as teachers and students' responses from interview.

The steps of learning model are pre-research, model design, model trial test, pilot test, model revision, and final implementation of the model. Data analysis in this study is students' score of performance and project tests measuring students' creative thinking skills using percentage as shown in Table III. 
TABLE III. ASSESSMENT RUBRIC

\begin{tabular}{|c|c|c|c|c|c|}
\hline Aspect & Description & $9-10$ & $7-8,9$ & $6-6,9$ & Remarks \\
\hline fluency & $\begin{array}{l}\text { - Coming up with a lot of } \\
\text { ideas, answers, solution, } \\
\text { and questions clearly; } \\
\text { - Coming up with a series of } \\
\text { problem-solving options; } \\
\text { - Coming up with more than } \\
\text { one answer }\end{array}$ & $\begin{array}{l}\text { Complete and informative } \\
\text { mind-map consisting of } \\
\text { more than five ideas (each } \\
\text { idea contains more than } \\
\text { two points), pictures and } \\
\text { symbols. }\end{array}$ & $\begin{array}{l}\text { Complete and } \\
\text { informative mind-map } \\
\text { consisting of five ideas } \\
\text { (each idea contains more } \\
\text { than two points), pictures } \\
\text { and symbols. }\end{array}$ & $\begin{array}{l}\text { Completer and } \\
\text { informative mind-map } \\
\text { consisting of four or } \\
\text { less ideas (each idea } \\
\text { contains one point), } \\
\text { pictures and symbols. }\end{array}$ & $\begin{array}{l}\text { Taken from mind- } \\
\text { map }\end{array}$ \\
\hline flexibility & $\begin{array}{l}\text { - Being able to raise up } \\
\text { various ideas, answers, and } \\
\text { questions, and to see a } \\
\text { certain problem from } \\
\text { different points of view; } \\
\text { - Searching for a series of } \\
\text { alternatives; } \\
\text { - Being able to shift } \\
\text { approahces and paradigms. }\end{array}$ & $\begin{array}{l}\text { Being able to come up with } \\
\text { five concepts properly }\end{array}$ & $\begin{array}{l}\text { Being able to come up } \\
\text { with four concepts } \\
\text { properly }\end{array}$ & $\begin{array}{l}\text { Being able to come up } \\
\text { with three or less than } \\
\text { three concepts } \\
\text { properly }\end{array}$ & $\begin{array}{l}\begin{array}{l}\text { Taken from spy } \\
\text { games }\end{array} \\
\begin{array}{l}\text { Taken from test } \\
\text { questions (no data } \\
\text { yet) }\end{array}\end{array}$ \\
\hline originality & $\begin{array}{l}\text { - Being able to come up with } \\
\text { new and unique } \\
\text { expressoins; } \\
\text { - Being able to come up with } \\
\text { antimainstream way to } \\
\text { express themselves; } \\
\text { - Being able to create } \\
\text { antimainstream } \\
\text { combination from certain } \\
\text { parts. }\end{array}$ & $\begin{array}{l}\text { Poster layout is interesting, } \\
\text { well-managed, and } \\
\text { consisting of explanation } \\
\text { using their own words }\end{array}$ & $\begin{array}{l}\text { Poster layout is less } \\
\text { interesting, } \\
\text { managed, and consisting } \\
\text { explanation copied from } \\
\text { other resources }\end{array}$ & $\begin{array}{l}\text { Tata letak poster tidak } \\
\text { menarik, tidak rapi, } \\
\text { dan tidak ada } \\
\text { penjelasan. }\end{array}$ & $\begin{array}{l}\text { Taken from the } \\
\text { poster }\end{array}$ \\
\hline elaboration & $\begin{array}{l}\text { - Being able to develop an } \\
\text { idea or a produc; } \\
\text { - Being able to specify } \\
\text { details of an object, an } \\
\text { idea, or a situation to be } \\
\text { more interesting. }\end{array}$ & $\begin{array}{l}\text { Adding five points of } \\
\text { information related to the } \\
\text { province made } \\
\text { Adding five ornaments on } \\
\text { the pop-up of the provided } \\
\text { picture }\end{array}$ & $\begin{array}{l}\text { Adding three to four } \\
\text { points of information } \\
\text { related to the province } \\
\text { made }\end{array}$ & $\begin{array}{l}\text { Adding one to two } \\
\text { points of information } \\
\text { related to the province } \\
\text { made }\end{array}$ & $\begin{array}{l}\text { Taken from the pop } \\
\text { up and the poster }\end{array}$ \\
\hline
\end{tabular}

The numeric evaluation is then grouped qualitatively as shown in Table IV.

TABLE IV. CREATIVE THINKING ASSESSMENT CRITERIA

\begin{tabular}{|l|l|l|}
\hline No. & \multicolumn{1}{|c|}{ Score } & \multicolumn{1}{c|}{ Category } \\
\hline 1. & $9-10$ & High \\
\hline 2. & $7-8,9$ & Medium \\
\hline 3. & $6-6,9$ & Low \\
\hline
\end{tabular}

Meanwhile, teachers' responses though questionnaire were analyzed using interval analysis. The results of the interval analysis were classified hierarchically.

\section{RESULTS AND DISCUSSION}

The results of the study showed that the group of students performing as the subjects are various in each aspect of creative thinking. The data were analyzed based on the creative thinking skills indicators by Alvino [6], namely fluency, flexibility, originality, dan elaboration.

\section{A. Fluency}

In this aspect, $52.5 \%$ of the students were categorized high, $35 \%$ were in low category, and $12.5 \%$ were categorized low. Most of the students reached high performance of fluency due to the fact that the innovative and recreative learning process triggered them to have more "space" to express ideas, questions, and answers.

\section{B. Flexibility}

In flexibility aspect, $29 \%$ of them were categorized high, $59 \%$ of them were in medium category, and $12 \%$ were categorized low. The fact the students were still limited in finding alternate answers made most of them in the medium category.

\section{Originality}

In this aspect, $39 \%$ of them were categorized high, $48.5 \%$ were in medium category, and $12.5 \%$ of them were categorized low. In this aspect, the majority of the students were having new expressions and ideas and able to express them. 


\section{Aspek Elaboration}

In this aspect, $2 \%$ of the students were categorized high, $77 \%$ of them were in low category, and $21 \%$ of them were categorized low. This fact was a little bit ironic sinec elaboration was the most important aspect in creative thinking. However, most of the students appeared to be confused of giving the right answers as told by the teachers.

The anlaysis results implied that the students had potentials to have optimum creative thinking skills. The students showed good performance in the fluency aspect since they gave various questions and answers as well as created a variety of products. However, students did not have good performance of flexibity since the learning processes were still teacher-centered so that it was difficult for the students to see things from various points of view. Uniquely, they were good in the originality aspect for that they were able to discuss issues using up-to-date terms. This indicated that elementary school students were equal with students from other levels in facing rising issues. Ther other thing that needs to be paid attentions seriously was elaboration. There were very few of them showed good performance of thinking out of the box. This is due to the limited freedom of students to express themselves in the teaching and learning processes.

Implememtation of effective learning model was necessary to develop all aspects and students' creative thinking skills. In this study, a thematic integrated learning model of Islamic education was developed santrock, [7], Runco [8] etc. through such components as purposes, learning materials, learning procedure, evaluasion, and learning environment. The purpose of developing this model was to promote students' creative thinking skills. Thus, the materials to be conveyed were in accordance with the needs of creative thinking skills. Consequently, the evaluation should also focus to the purpose of the model developed. Usually the evaluation was the in the form of open-ended questions; therefore, multiple choice questions were no longer administered. This model represented students' way of thinking. The level of difficulty as well as the order of the questions was made based on the level of grade 5 .

The implementation consisted of pre-preparation, preparation, implementation, closing, and evaluation. The prepreparation was when the teacher prepared everything before the class. In has something to do with classroom management, sitting arrangement, putting on room perfume, and playing soft music. This was to welcome students so that they would feel comfortable when entering the classroom.

In the thematic-integrated model, the learning was designed based on the principles of integrative learning. This learning model was considered suitable since it was most likely to stimulate the students to think creatively through more space for them to express themselves. Thefore, the roles of the teachers were more of facilitators and guides in the learning process. On the other hand, the students were more actively engaged in the learning process by expressing original ideas in designing a project.

Below are points that could be developed in thematicintegrated model to promote students' creative thinking skills:

- Determining subjects to integrate;
- Selecting interesting themes in accordance with the students' age

- Focusing the role of the teachers to be facilitators

- Giving more space literally and figuratively so that students can be more creative

- Providing classes which support students' mobility

- Having valid and accurate evaluation

- Constantly improving teachers' competences

The results of the current study was in a agreement with hose of Siti Marwiyah [9] that creative thinking skills would be likely to occur in a fun and relaxing situation. This idea was in line with Rofi'udin [10] who stated that learning situtations which can give students more space to express themselves could promote their creative thinking skills better than those did not. In addition, it has been also proven that students in a innovative learning model outperformed those in a traditional learning model in terms of creative thinking [11].

\section{CONCLUSIONS}

Elementary school students' creative thinking skills showed good improvement in the aspects of fluency and originality which referred to the ability of giving a plenty of questions and answers as well as stating opinions in an up-to-date way. However, in the aspects of flexibility and elaboration, which referred to an ability to elaborate ideas, specify detailed information, and giving out of the box answers, was still low. This was caused by the teaching and learning processed which were still teacher-centered. Thus, the teachers were still dominating so that the students did not have enough space to express themselves.

The fact that the thematic-integrated Islamic education curriculum improved the aspects of fluence and originality yet did not improve the other two aspects indicated that the model could actually improve students' creative thinking skills in general as long as several requirements were fulfilled. The requirements were: the ability of the teachers to integrate and implement a variety of learning models, adequate facilities, and the presence of conducive learning environment. In short, students abilities related to creative thinking skills will emerge when the learning process is student-centered.

There had been several recommendations in this study as follows (1) teachers and the school is to develop and integrate innovative learning models; (2) teachers should be more of facilitators to give the students more space to express themselves; (3) the schools should provide more flexible classrooms; (4) further researchers are expected to develop assessment which can measure students' creative thinking skills; and (5) teachers are to keep developing themselves to be able to promote creative thinking.

\section{REFERENCES}

[1] Zuhairini, Filsafat Pendidikan Islam, Jakarta: Bumi Aksara, 1995, 98.

[2] P. Vito, "On standardized testing." Childhood Education 67.3, 131-142, 1991. 
[3] Mayadiana, D. Pembelajaran dengan pendekatan Diskursif untuk meningkatkan kemampuan berpikir kritis matematik mahasiswa calon guru Sekolah dasar, Tesis pada SPS UPI, tidak diterbitkan, 2005.

[4] Trianggono, Mochammad Maulana. "Analisis Kausalitas Pemahaman Konsep Dengan Kemampuan Berpikir Kreatif Siswa Pada Pemecahan Masalah Fisika." Jurnal Pendidikan Fisika dan Keilmuan (JPFK) 3.1 112. 2017.

[5] Hasanah, A., Gustini, N., and Rohaniawati, D. "Cultivating Character Education Based on Sundanese Culture Local wisdom". Jurnal Pendidikan Islam, 2(2), 231-253. 2016.

[6] C. Kathleen, "Teaching thinking skills". Northwest Regional Educational Laboratory, School Improvement Program, 1991.

[7] Santrock J. W. "A topical approach to life-span development, 3E." Ch 5, 192. 2007.
[8] Runco, M. A. "A hierarchical framework for the study of creativity". New Horizons in Education, 55(3), 1-9. 2007.

[9] Marwiyah, Siti, Kamid Kamid, and Risnita Risnita. "Pengembangan Instrumen Penilaian Keterampilan Berpikir Kreatif pada Mata Pelajaran IPA Terpadu Materi Atom, Ion, dan Molekul SMP Islam Al Falah." Edu-Sains: Jurnal Pendidikan Matematika dan Ilmu Pengetahuan Alam Universitas Jember 4.1, 2015.

[10] Rofi'uddin, A. "Model Pendidikan Berpikir Kritis-Kreatif Untuk Siswa Sekolah Dasar”. Majalah Bahasa dan Seni 1(28) Pebruari : 72-94. 2000.

[11] Arnyana, I. B. P. Pengaruh Penerapan Strategi Pembelajaran Inovatif pada Pelajaran Biologi Terhadap Kemampuan Berpikir Kreatif Siswa, Jurnal pendidikan dan pengajaran IKIP negeri Singaraja no 3. 2006. 